sciendo Порівняльна професійна педагогіка 8(3)/2018

Comparative Professional Pedagogy 8(3)/2018

DOI: $10.2478 /$ rpp-2018-0037

PhD in Pedagogy, Associate Professor, NADIYA TYMKIV Ivano-Frankivsk National Technical University of Oil and Gas, Ukraine Address: 15 Karpatska St., Ivano-Frankivsk, 76018, Ukraine E-mail: nadia_tymkiv@ukr.net

\title{
FORMING COMPETENCE OF SOCIAL RESPONSIBILITY IN VOCATIONAL TRAINING OF FUTURE PETROLEUM ENGINEERS (BASED ONFOREIGN SCHOLARS' VIEWS)
}

\begin{abstract}
The article deals with the issue of forming competence of social responsibility in vocational training of future petroleum engineers in Ukraine and abroad. Various views on the essence of social responsibility, particularly by means of higher technical education, have been given. It has been stated that many scholars have thoroughly focused on the essence of social responsibility used by higher education systems of different countries. The article also emphasized that social responsibility can be examined in terms of obligation, reaction and responsiveness. Therefore, it has been presented that social responsiveness are actions that exceed social obligation and social reaction. Additionally, the essence of social responsibility appears to be associated with perseverance and self-discipline. The foreign pedagogical experience referring to social responsibility provides a focal aspect of the role of the professional educator and vocational training throughout the world. Comparative studies of social responsibility are quite infrequent, typically as opposed to other connected areas, like comparative management, law or governance. It is stressed on an instructive interference in learning activities which inquired to train future petroleum engineers more excellent to evaluate severely all pros and cons of social responsibility that is a way to integrating the concerns of the industry and society. Based on the analysis of scientific and reference sources and international documents it has been concluded that a high percentage of universities include social responsibility related subjects on their curriculum. Social responsibility is taught as either specific social responsibility subjects or as a part of various subjects on the academic curriculum.

Keywords: social responsibility, comparative studies of social responsibility, training of petroleum engineers, foreign experience, professional competences, interdisciplinary course, curriculum, professional educators, engineer professional development.
\end{abstract}

\section{INTRODUCTION}

The compelling advance of society necessitates worldwide influential people, chairmen, and leaders to be proficient for the competence of social responsibility. This transferable ability specifies a proper foundation to operate with the perception necessary to realize the tremendously intermixed civil, economic and physical results of peculiar solutions accepted, maintaining a view of continuing systems for the welfare of humankind in total. Scarcity for the competence social responsibility by leaders in any area, for instance, business, management, production or technology, may have implications in selections that can put in jeopardy the growth of current and new age groups.

It is a firm belief that social responsibility is an interdependent skill that ought to be obtained from a curriculum, demanding further growth during any engineer career. 
Appropriately, petroleum HEIs due to their curricula, learning plans and professional organizations and due to their professional code of ethics endure a candid authority to expand a solid competence for social responsibility of leaders in their area.

The procedure of acquiring skill of social responsibility by future petroleum engineers is related to a complete education for balanced growth given from HEIs. A comprehensive teaching demands not merely newing curricula, it although includes newing the campus (Koester et al, 2006).

\section{THE AIM OF THE STUDY}

Our study is aimed at showing the relationship between petroleum engineering and the competence of social responsibility, the contemporary prevailing context taken by the petroleum sector to develop companies' commitments to all their collaborators because it has a slight part in petroleum ethics training.

\section{THEORETICAL FRAMEWORK AND RESEARCH METHODS}

Theoretical and methodological aspects of our study are based on standout works by the outstanding scholars like M. Barth, S. Babidge, J. Boynton, A. Cortese, C. Didier, J. G. Frynas, R. Huet, D. M. Hussey, P. L. Kirsop, C. J. McClelland, R. E. Meissen, J. M. Smith and others are keen to teach the future generation of petroleum engineers to be well-rounded professionals who consider the technical and social aspects and the broader effects of their activities. Their current researches involve pedagogical interventions in labs and lecture rooms, including how to best teach technical and professional competences. Formed on the above-underlined scholars' analyses it has been claimed that it is exceedingly meaningful to deliver such a notion as social responsibility in technical and social aspects of petroleum threats that are appropriate to future jobs, expand learners' complicatedness of outlook regarding social obligation.

The petroleum industry introduces peculiar callings to its specialists who are occasionally obliged to operate contesting general patterns and codes of behavior, various commitments, shared beliefs, values and responsibilities, the importance of individual dignity, social responsibility approaches of their management (M. Blowfield, J. Boutelle, L. Bucciarelli, S. Costa, G. Catalano, D. Douglas, J. G. Frynas, G. Papadopoulos, M. Scoble and others). In short, the competence of social responsibility is the contemporary prevailing core taken by the petroleum sector to develop companies' commitments to all their collaborators because it has a slight part in petroleum ethics training.

To reach the goal of the study we have used such methods as theoretical analysis, systematization, generalization, synthesis, comparative analysis.

\section{RESULTS}

Various surveys assume that our Earth will achieve its moving scope with current population rise proportion and exploit of natural resources eventually (Meadows et al, 1972; Meadows, \& Randers, 2004). Luckily, these researches focus on a design of steady growth that faces the up-to-day demands without bargaining the readiness of next age groups to satisfy their individual requirements (World Commission on Environment and Development, 1987). The proposed design considers a foreseen boost of industrial effectiveness, but the most momentous need is a difference in society's style of living. What is more, people should substitute their consumption habits accelerating the exploit of renewable resources, rising current recycling scope and assessing the influence created by goods in time of their circulation. Additionally, productive next advances for the human race need comprising social integrity too. This explains in a regular growth of living 
sciendo Порівняльна професійна педагогіка 8(3)/2018

Comparative Professional Pedagogy 8(3)/2018

conditions and prosperity for current and next generations considering the economic, medium and social results of all implemented activities.

Having the right degree or diploma is no guarantee of promotion, but the right attitude, good communication skills will get petroleum engineers and the competence of social responsibility a long way. Also, petroleum professionals need to enjoy the challenge of working in a unique focused environment. That is to say that it is of great importance to realize how innovative competences are obtained in this field because of the arrangement of competences applied on-site in the extraction of oil and gas, both onshore and offshore.

It is generally accepted that an essential requirement for future petroleum engineers to be proficient for the competence of social responsibility is that HEIs have used a holistic training system for sustainable growth in conjunction with curricula, different researches, campus activities etc. HEIs worldwide present a differential way to use such a model. It is necessary to use an approach to evaluate the level of readiness accomplished by a HEI to take a holistic model of learning for sustainable growth. There are various ways for it, e. g., the Auditing Instrument for Sustainable Higher Education (Rooda, 2010), the Graphical Assessment for Sustainability in Universities (Lozano, 2006), Sustainability Tracking, Assessment \& Rating System (AASHE, The STARS Program, 2016) or the Quality System of Science and Technology Universities for Sustainable Industry (QUESTE-SI, 2016), all documents are formed on the grounds of quality support means.

The first instrument was provided by the Dutch committee for steady higher education who developed the Auditing Instrument for Sustainable Higher Education (AISHE). In this approach the idea is that organization is regarded as one of some progress steps according to a series of ratios. AISHE comprises four areas: vision and policy, expertise, intructive objectives and methodology, training details.

The process involves an investigation of four areas to be over with a selfevaluation description that can be inspected outwardly (Rooda, 2010). Another method to evaluate the level of progress of HEIs in training for balanced progress is the Graphical Assessment for Sustainability in Universities (GASU) (Lozano, 2006), dependent on the Global Reporting Initiative balanced markers (Hussey et al, 2001), determined to show peculiar ways of the learning delivered at universities together with education, research, campus operations and community exceed. Its pluses are in its multistakeholder suggestion and its sets of signs in the social, economic and environmental aspects.

The Sustainability Tracking, Assessment \& Rating System (STARS) is a selfevaluation instrument created for a HEI to get points formed on the efficiency on different parts connected to steady advance united in four aspects: academic, engagement, operations and planning and administration. The last score allows realizing the level of comprising of a HEI in balanced growth (AASHE, The STARS Program, 2016). At last, the Quality System of Science and Technology Universities for Sustainable Industry (QUESTE-SI) is a quality assurance scheme, which holds up quality increase of balanced educational growth at HEIs.

It needs the illustration of internal evaluation information that is pursued by an inspector group external assessment. QUESTE-SI evaluation is placed on the information obtained from four parts: institution strategy, education and curriculum, students' involvement and research and innovation (QUESTE-SI, 2016). Likewise STARS, after the assessment HEIs receive total points that notify the current institutional rank regarding steady growth and contributes to find out cons of their upgrading. These methods, however, are created to evaluate the level of adopting education for balanced growth of HEIs, it is predicted that a more holistic way of establishments in planning a model on education for 
steady growth will contribute to a higher achievement of future proficient specialists for the competence of social obligation, even though that demands to be further investigated.

The course module stressing on the medium aspects of the competence of social duty should start to be delivered to future engineers. In essence, scholars of this ability keep emphasizing it in a petroleum engineering curriculum. The engineering educators assume after the module learners are more capable to determine all elements of this term which is categorized as social, such as society progress or communication. Even in the case when learners become more aware with the social aspects of this skill, they are not ready to define a function for experts in this field. At the same time it is essential for learners to identify the restrictions of their learning and look for special knowledge from other subjects, assisting future specialists to understand how engineers and petroleum engineering are precisely involved in matters that are considered as basically social points and aid to make clear both social and technical scopes of their qualified work.

\section{CONCLUSIONS}

Summing up the analysis of the competence of social responsibility, as well as some conceptual clarifications on the notion of social responsibility we can define that social responsibility is the term that converses to a feature that incorporates decisive actions. These actions can be characterized as intentional acts that are fulfilled using sufficient instruments to achieve goals in certain situations and are regarded as proper and precise in our times. The foreign pedagogical experience referring to social responsibility provides a focal aspect of the role of the professional educator and vocational training throughout the world. Comparative studies of social responsibility are rather opposed to other connected areas, like comparative management, law or governance. Also, scholars stress on an instructive interference in learning activities which inquired to train future petroleum engineers more excellent to evaluate severely all pros and cons of social responsibility that is a way to integrating the concerns of the industry and society. The obtained results testify that social responsibility is placed in undergraduate and graduate curricula, aims, teaching methods and textbooks. It is worth pointing out that social responsibility has been acquiring much importance in all the fields, particularly in higher technical education. Many scholars have thoroughly focused on the essence of social responsibility used by higher education systems of different countries and indicated that social responsibility can be examined in terms of obligation, reaction and responsiveness. Furthermore, it has been emphasized that social responsiveness are actions that exceed social obligation and social reaction. Based on the analysis of scientific and reference sources and international documents it has been concluded that a high percentage of universities include social responsibility related subjects on their curriculum. Also, social responsibility is taught as either specific social responsibility subjects or as a part of various subjects on the academic curriculum.

\section{REFERENCES}

1. AASHE, The STARS Program. (2016). AASHE's Sustainability Tracking, Assessment \& Rating System. The Association for the Advancement of Sustainability in Higher Education, Denver, Colorado, USA. Retrieved from http://www.aashe.org/ files/documents/STARS/ stars_2.1_technical_manual.pdf).

2. Association Leaders for a Sustainable Future. (1990). Report and Declaration of the Presidents Conference. Retrieved from http://www.ulsf.org/programs_talloires.html. 
sciendo Порівняльна професійна педагогіка 8(3)/2018

Comparative Professional Pedagogy 8(3)/2018

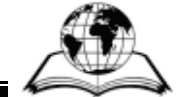

3. Barth, M., \& Michelsen, G. (2013). Learning for change: an educational contribution to sustainability science. Sustainability Science, 8, 103-119.

4. Barth, M., \& Timm, J-M. (2011). Higher Education for Sustainable Development: Students' Perspectives on an Innovative Approach to Educational Change. Journal of Social Sciences, 7, 13-23.

5. Buckler, C., \& Creech, H. (2015). Shaping the future we want: UN Decade of Education for Sustainable Development (2005-2014); final report. Retrieved from http://unesdoc. unesco.org/images/0023/002301/230171e.pdf.

6. Cortese, A. D. (2003). The critical role of higher education in creating a sustainable future. Planning for Higher Education, 31 (3), 15-22.

7. Didier, C., \& Huet, R. (2008). Corporate social responsibility in engineering education. A French survey. European Journal of Engineering Education, 33 (2), 169-177.

8. Dobson, A. (2007). Green Political Thought. (4th ed). London: Routledge.

9. Frynas, J. G. (2009). Corporate social responsibility in the oil and gas sector. Journal of World Energy Law and Business, 2 (3), 178-195.

10. Hussey, D. M., Kirsop, P. L., \& Meissen, R. E. (2001). Global reporting initiative guidelines: an evaluation of sustainable development metrics for industry. Environmental Quality Management, 11 (1), 3-20.

11. Koester, R.J., Eflin, J., \& Vann, J. (2006). Greening of the campus: a wholesystems approach. Journal of Cleaner Production, 14, 769-779.

12. Lozano, R. (2006). A tool for a Graphical Assessment of Sustainability in Universities (GASU). Journal of Cleaner Production, 14, 963-972.

13. Lozano, R., Ceulemans K., Alonso-Almeida M., Huisingh D., Lozano F.J., Waas T., Lambrechts W., Lukman R., Hug J. (2015). A review of commitment and implementation of sustainable development in higher education: results from a worldwide survey. Journal of Cleaner Production, 108, 1-18.

14. Meadows, D. H., \& et al. (1972). The Limits to Growth: a report for the Club of Rome's project on the predicament of mankind. Boston: Universe Books.

15. Meadows, D., \& Randers, J. (2004). Limits to Growth: The 30-Year Update. Chelsea Green Publishing Company, White River Junction, VT.

16. QUESTE-SI. (2016). Quality System of Science and Technology Universities for Sustainable Industry. Retrieved from http://plone.queste.eu. University.

17. Rooda, N. (2010). Sailing in the winds of change. Ph. D. Thesis. Maastricht

18. Smith J. M., McClelland C. J., Smith N. M. (2017). Engineering Students' Views of Corporate Social Responsibility: A Case Study from Petroleum Engineering. Science and Engineering Ethics, 23 (6), 1775-1790.

19. United Nations, treaty collection. (2015). Paris Agreement to the United Nations Framework Convention on Climate Change. Retrieved from https://treaties.un.org/ pages/ViewDetails.aspx-?src=TREATY\&mtdsg_no=XXVII-7-d\&chapter=27\&lang=en.

20. World Commission on Environment and Development. (1987). Our common future. New York, NY: Oxford University Press. 